\title{
Dissolved Solids in Basin-Fill Aquifers and Streams in the Southwestern United States - Executive Summary
}

\begin{abstract}
The U.S. Geological Survey (USGS) recently completed a regional study in the Southwestern United States to characterize dissolvedsolids conditions in major water supplies, including important rivers and aquifers. High concentrations of dissolved solids can degrade a water supply's suitability for important uses, such as drinking water or crop irrigation. In an effort to ensure the continued availability of clean surface and groundwater, USGS scientists identified areas where there have been both increasing and decreasing trends in dissolved-solids concentrations.
\end{abstract}

Major water supplies support significant economic and cultural activities in the Southwestern United States. These water supplies include the Colorado River, the Rio Grande, their tributaries, several smaller rivers, and basin-fill aquifers, such as the Rio Grande aquifer system, Basin and Range basin-fill aquifers, and California Coastal Basin aquifers. All water naturally contains dissolved solids as a result of the weathering and dissolution of minerals in soils and geologic formations. Major ions, such as bicarbonate, calcium, chloride, magnesium, potassium, silica, sodium, and sulfate, constitute most of the dissolved solids in water and are an indicator of salinity. High concentrations of dissolved-solids in water, generally those greater than $500 \mathrm{mg} / \mathrm{L}$, can degrade a water supply's suitability for certain uses. For domestic, municipal, and industrial users, high concentrations can result in objectionable taste to drinking water; greater watertreatment costs, increased use of detergents and soaps, and the encrustment or corrosion of metallic surfaces and associated reduction in appliance or equipment lifespan. For irrigation users, high concentrations can result in decreased crop production or crop death, and thus, decreases in economic returns.

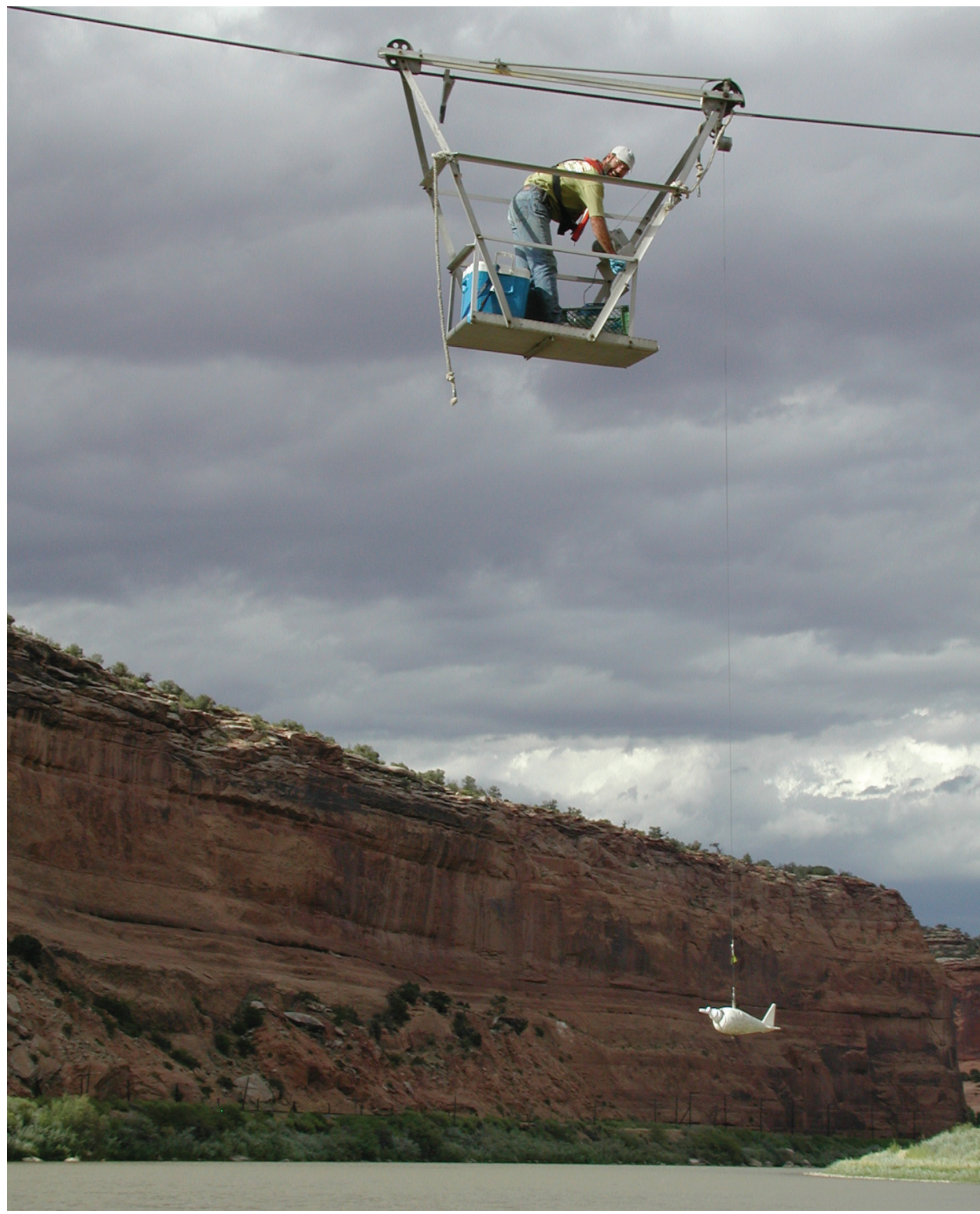

A U.S. Geological Survey scientist collects a sample from the Colorado River for analysis of dissolved solids and other water-quality constituents (USGS photograph by Nancy Bauch).

The U.S. Geological Survey (USGS) National Water-Quality Assessment Program recently completed a regional study in the Southwest to characterize dissolved-solids conditions in these important water supplies. The study focused on addressing questions regarding (1) spatial variation, (2) effects of natural and human factors, (3) sources, trans- port, accumulation, and (4) long-term trends of dissolved solids in these water supplies. This summary highlights some of the major findings of the report, "Dissolved-Solids in Basin-Fill Aquifers and Streams in the Southwestern United States," USGS Scientific Investigations Report 2006-5315, available at http://pubs.usgs.gov/sir/2006/5315/. 


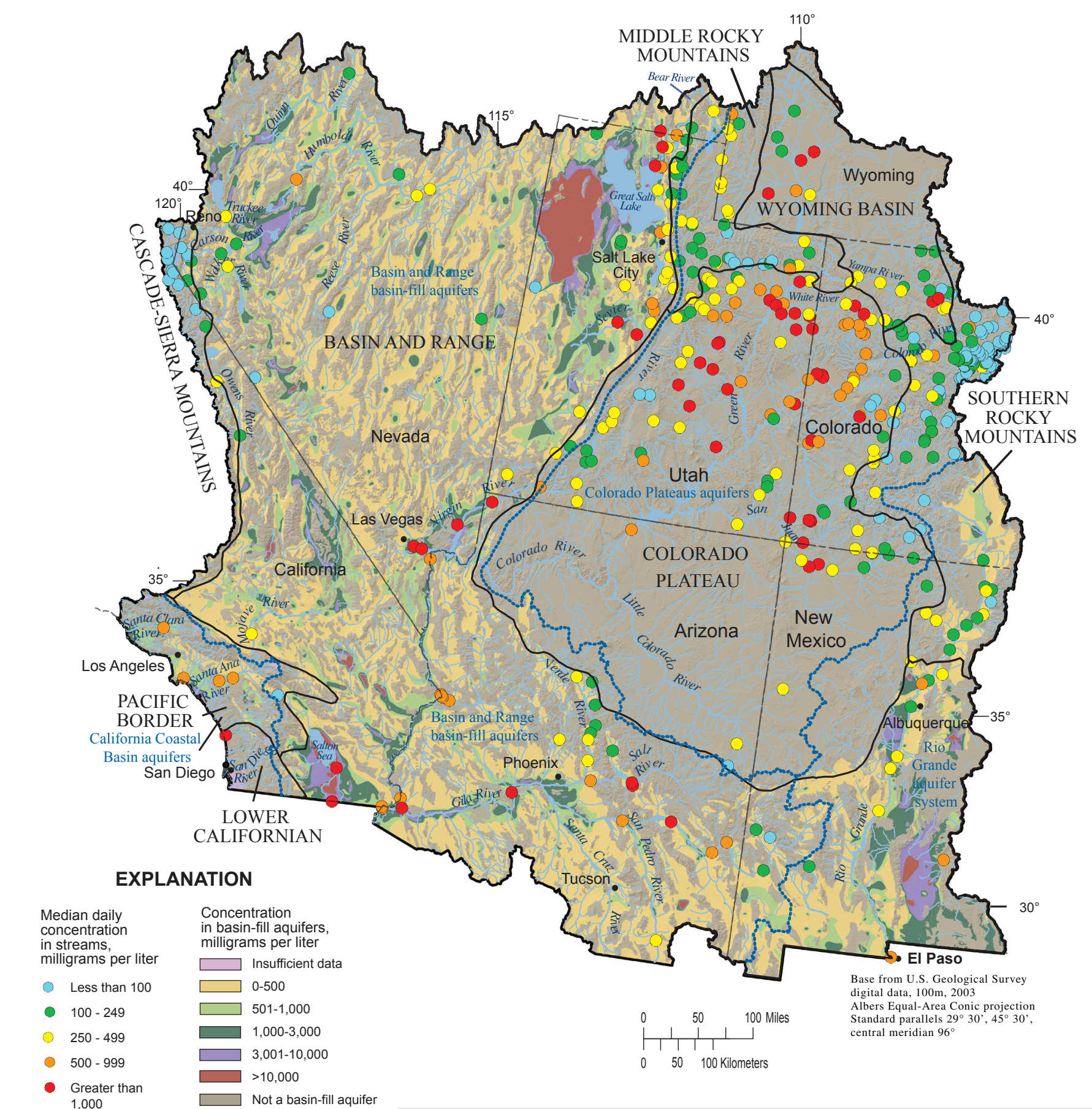

Principal Aquifer boundary--Annotation, Rio Grande aquifer system, is principal aquifer name Physiographic Province boundary--

Annotation, BASIN AND RANGE, is physiographic province name

\section{How Variable are Dissolved-Solids Concentra- tions Across the Southwest?}

Dissolved-solids concentrations of ground water in the basin-fill aquifers of the Southwest ranged from less than $500 \mathrm{mg} / \mathrm{L}$ near basin margins where ground water is recharged from nearby mountains to more than $10,000 \mathrm{mg} / \mathrm{L}$ in topographically low areas of some basins or in areas adjacent to specific streams or rivers in the Basin and Range and Rio Grande aquifer systems. The U.S. Environmental Protection Agency non-enforceable secondary drinking water regulation of $500 \mathrm{mg} / \mathrm{L}$ for dissolved solids was established to govern esthetic qualities of water, such as taste. The area of the basin-fill aquifer systems with dis- solved-solids concentrations less than or equal to $500 \mathrm{mg} / \mathrm{L}$ was about $57 \%$ for the Rio Grande aquifer system, $63 \%$ for the Basin and Range basin-fill aquifers, and $44 \%$ for the California Coastal Basin aquifers. At least $70 \%$ of the area of each of these three basin-fill aquifer systems had dissolved-solids concentrations less than or equal to $1,000 \mathrm{mg} / \mathrm{L}$. Dissolved-solids con- 
centrations greater than $3,000 \mathrm{mg} / \mathrm{L}$ were found in topographically low areas with brackish or saline lakes, playas, and terminal basins, such as the Great Salt Lake and Desert in Utah; the Mojave Desert with its many playas, Death Valley, and Salton Sea area in California; the Black Rock Desert and Carson and Humboldt Sinks in Nevada; and the Tularosa Basin in New Mexico. Dissolved-solids concentrations greater than $3,000 \mathrm{mg} / \mathrm{L}$ were also found in ground water in the Basin and Range and Rio Grande aquifer systems near or along drainages of the Virgin, Gila, and lower Salt Rivers in the Colorado River Basin, and the Jemez River and Rio Puerco in the Rio Grande Basin.

Dissolved solids in streams were described on the basis of median daily concentration, median annual load, and median annual yield data for 420 surface-water-quality monitoring sites. The time period for which dissolved-solids data was available for individual sites varied, but it was at least 10 or more years between 1974 and 2003. Median dissolved-solids concentrations vary markedly among the sites in the Southwest, ranging between 22 and 13,800 $\mathrm{mg} / \mathrm{L}$, and also vary between different sites on the same stream. Median daily dissolvedsolids concentrations less than $100 \mathrm{mg} / \mathrm{L}$ are predominately found at sites in the headwaters of the Rio Grande, Colorado, Green, San Juan, Truckee, and Carson Rivers. These areas are underlain by igneous and metamorphic rocks that are relatively resistant to the solvent action of water. Median daily dissolved-solids concentrations greater than or equal to $500 \mathrm{mg} / \mathrm{L}$ are predominately found in streams in contact with less resistant, more soluble sedimentary rocks, such as those found on the Colorado Plateau physiographic province. Median daily concentrations generally increased in a downstream

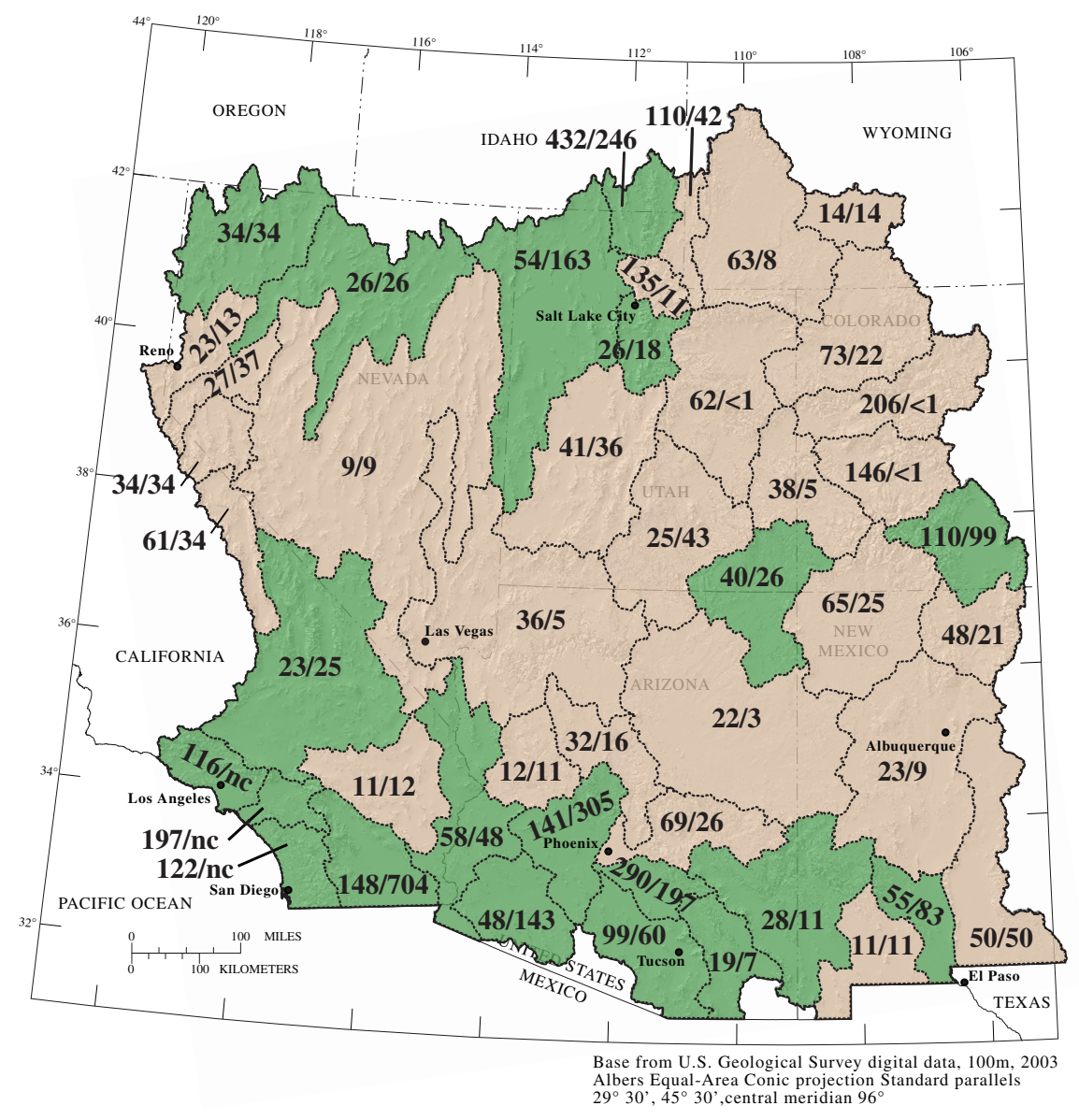

\section{EXPLANATION}

PREDOMINANT INTERNAL SOURCE OF DISSOLVED SOLIDS WITHIN ACCOUNTING UNIT

Natural - geologic units

Human - cultivated and pasture lands

-..... HYDROLOGIC ACCOUNTING UNIT BOUNDARYNumbers, 23/25; left number is delivery rate of dissolved solids from internal sources and right number is internal accumulation rate of dissolved solids, both in units of tons/year per square mile of accounting unit. nc, not computed.

direction for sites on the Rio Grande, Colorado, Yampa, White, Green, San Juan, Gila, Bear, and Sevier Rivers.

\section{What Factors Affect Dissolved Solids?}

Several natural and human factors affect dissolved-solids concentrations in streams from their headwaters to their mouths and in ground water along flow paths from recharge areas to discharge areas. Factors that affect concentrations in upland mountain streams include (1) the amount of low-concentration runoff to the stream available to mix with and dilute higher-concentration base flow; (2) presence of sedimentary rocks in the drainage basin that are less resistant to the solvent action of water, especially evaporite deposits; (3) streamflow storage and mixing processes in reservoirs; (4) evapotranspiration, which concentrates the dissolved solids; and (5) transbasin diversions that result in the removal of low-concentration water that would otherwise serve to help dilute high-concentration water sources in the originating basin.

Streams flow out of upland mountain areas and into lowland areas that have flatter terrain and contain large basin-fill aquifers. Groundwater recharge of the basin-fill aquifers largely occurs along the basin margin by streamflow infiltration, or by subsurface flow from adjacent bedrock highland aquifers. Ground water in recharge areas typically has low dissolved-solids concentrations in comparison to ground water in other parts of the aquifer. Dissolved-solids concentrations in ground water typically increase along flowpaths through basin-fill aquifers as a result of (1) geochemical reactions with the aquifer matrix, (2) dissolution of disseminated salts and massive evaporite deposits, and (3) evapotranspiration of shallow ground water by natural vegeta-

This map shows delivery rate of dissolved solids from internal sources, internal accumulation rate, and predominant internal source of dissolved solids within accounting units in the Southwestern United States. Dissolved solids are delivered to streams from natural and human sources. The delivery rates and the relative share from these sources vary for hydrologic accounting units in the Southwestern United States. Losses of dissolved-solids from streams, either due to stream diversions or due to streambed infiltration, accumulate in the subsurface and may degrade ground water. Accumulation rates also vary by hydrologic accounting unit. 
tion or by agricultural crops. Dissolved-solids concentrations also can change as a result of (1) mixing two or more subsurface waters; (2) recharge from irrigation seepage, septic tank seepage, and percolation ponds or streambeds that infiltrate imported water or treated municipal wastewater; or (3) seawater intrusion (in coastal areas). Most of these processes result in increased concentrations in the ground water. As streams flow through lowland areas, dissolved-solids concentrations in streams also change due to evapotranspiration, mixing with ground water, irrigation-return flows, or releases from municipal wastewater-treatment plants. Usually the change is an increased concentration downstream.

In lowland areas, the enhancement or restriction of surface-water and ground-water outflow affects the accumulation of dissolved solids in water supplies. Natural drainage or artificial drainage by canals or pipelines can enhance the outflow of water containing dissolved solids, thereby diminishing the accumulation of salts. Restriction of outflow through water use, or through natural features like topographic barriers that prevent surface outflow, promotes the accumulation of salts. The salts generally accumulate in areas with high evapotranspiration, a process that increases dissolved-solids concentrations and can impair the quality of a ground-water resource.

\section{Where Do Dissolved Solids Come From and Where Do They Accumulate?}

Significant dissolved-solids source and accumulation areas were determined by using a mass-balance analysis of the contributions (inflows, internal deliveries, and imports) and losses (outflows, internal accumulation, and exports) of dissolved solids for river systems in hydrologic accounting units of the Southwest. Quantification of contribution and loss terms was facilitated by using a spatially referenced regression model of contaminant transport on watershed attributes. Hydrologic accounting units are large river basins that were defined nationwide and average about 16,000 square miles $\left(\mathrm{mi}^{2}\right)$ each in the Southwest.

The relative contribution from natural and human sources and the delivery rates for internal sources of dissolved solids vary by accounting unit. The most significant dissolved-solids source areas in the Southwest included the Colorado Headwaters, Middle Gila, Lower Bear, and Santa Ana hydrologic accounting units, where deliveries from internal sources were greater than 150 (ton/year)/ $\mathrm{mi}^{2}$. Overall, geologic units contribute $44 \%$ of the total internal deliveries for all hydrologic accounting units in the Southwest-about $7 \%$ is from crystalline and volcanic rocks, $2 \%$ is from eugeosynclinal rocks, $12 \%$ is from Tertiary sedimentary rocks, $12 \%$ is from Mesozoic sedimentary rocks, and $10 \%$ is from Paleozoic and Precambrian sedimentary rocks. Cultivated lands (44\%) and pasture lands $(12 \%)$ contribute the remaining $56 \%$ of the total internal deliveries for all Southwest accounting units.

Some of the dissolved solids delivered to streams in an accounting unit accumulate internally as a result of streambed infiltration or by infiltration of diverted water through soils in offstream locations. The most significant dissolved-solids accumulation areas include the Salton Sea, Lower Gila-Agua Fria, Middle Gila, Lower Bear, and Great Salt Lake hydrologic accounting units, where accumulation rates were greater than 150 (ton/ year) $/ \mathrm{mi}^{2}$. The dissolved-solids accumulation rate for the Salton Sea hydrologic accounting unit, 704 (ton/year) $/ \mathrm{mi}^{2}$, was more than twice as high as the second highest rate, 305 (ton/ year)/mi for the Lower Gila-Agua Fria hydrologic accounting unit.

\section{Are Dissolved-Solids Concentrations Increas- ing or Decreasing Over Time?}

Trends for 1974-1988, 1989-2003, and 1974-2003 were determined for concentrations of dissolved solids in basin-fill aquifers and for flow-adjusted and seasonal-adjusted concentrations in streams. For the basin-fill aquifers, concentrations of dissolved solids did not change over time for most ground-water-quality monitoring wells in the analysis. The percentage of wells in basin-fill aquifers with either an increasing or decreasing trend in concentrations was $23 \%$ for $1974-1988,32 \%$ for $1989-2003$, and $41 \%$ for $1974-2003$. Of the wells that had a trend in concentrations, increasing trends were more common than decreasing trends for each period. The trends were not focused in any particular part of the Southwest, which suggests that trends occur in localized areas and not across large regions. For 1989-2003, wells with depths to water only a few feet below the land surface were the most likely to have trendsabout a $42 \%$ chance. The likelihood of a trend in concentration occurring decreases steadily with depth to water below the land surface and is about $5 \%$ where depth to water is 1,000 feet.

In comparison to conditions for groundwater-quality monitoring wells in the basin-fill aquifers, the presence of trends in dissolvedsolids concentrations in streams was much more common and many decreases were observed. Of the three periods, 1974-1988 had the greatest percentage of sites with either no change or an increase in concentration. For this period, concentrations increased at $34 \%$ of the sites, did not change at $24 \%$ of sites, and decreased at 42\% of sites. During 1989-2003, concentrations decreased at $51 \%$ of the sites, and there were five river basins where concentrations decreased at $75 \%$ or more of the sites. For several areas in the Colorado River Basin, concentrations decreased during 1989-2003 at all sites downstream from salinity-control units, whereas increasing and decreasing concentrations trends occurred at sites upstream from the units. Decreases in concentrations occurred at three sites above salinity-control units but were much less than the decreases at sites below those units. For 1974-2003, concentrations decreased at about $70 \%$ of the sites, and the median change in concentration during this period for all sites was a decline of about $8 \%$. Most of the sites included in the trend analysis for this period are on the main stem of major rivers, and as a result, the conclusions that are drawn from this data set relate more specifically to conditions in the major rivers.

High concentrations of dissolved solids can degrade a water supply's suitability for important uses, such as drinking water or irrigation. This study of dissolved-solids conditions in the important water supplies of the Southwest is only part of the USGS National WaterQuality Assessment Program's efforts to help understand and ensure the future availability of our Nation's freshwater supplies.

David W. Anning

Edited by James W. Hendley II Graphic design by Judy Weathers

\begin{tabular}{|c|}
\hline For further information, contact: \\
David W. Anning, Hydrologist \\
U.S. Geological Survey Arizona \\
Water Science Center \\
Northern Arizona Programs \\
2255 N. Gemini Drive \\
Flagstaff, AZ 86001 \\
email: dwanning@usgs.gov \\
or \\
http://az.water.usgs.gov \\
See also Dissolved Solids \\
in Basin-Fill Aquifers and Streams in the \\
Southwestern United States \\
(USGS Scientific Investigations Report 2006-5315; online at \\
http://pubs.usgs.gov/sir/2006/5315/) \\
This Fact Sheet and any updates to it are available online at \\
http://pubs.usgs.gov/fs/2008/3076/ \\
\hline
\end{tabular}

